\title{
Geophysical prospecting for iron ore deposit around Tajimi village, Lokoja, North-Central Nigeria
}

\section{Geofizikalna prospekcija železovih nahajališč pri vasi Tajimi v pokrajini Lokoja v severni centralni Nigeriji}

\author{
Oyelowo Bayowa', Gbenga Ogungbesan ${ }^{1, *}$, Razak Majolagbe $_{2}$, Simeon Oyeleke $^{1}$ \\ ${ }^{1}$ Department of Earth Sciences, Ladoke Akintola University of Technology, P.M.B. 4000, Ogbomoso, Oyo State, Nigeria. \\ ${ }^{2}$ BeeM Geophysics and Borehole Drilling Company, Ibadan, Nigeria \\ *googungbesan@lautech.edu.ng
}

\begin{abstract}
Ground magnetic and electrical resistivity survey were undertaken to investigate the occurrence and geometry of iron ore deposit around Tajimi village, Lokoja, North-Central Nigeria. The generated residual map of the ground-magnetic data acquired at 250 stations along 15 traverses revealed numerous prominent anomalies, mostly trending in the $\mathrm{N}-\mathrm{S}$ direction. The radial power spectrum revealed the depth to magnetic sources between $6 \mathrm{~m}$ to $20 \mathrm{~m}$. The interpreted VES data characterized the area into three subsurface layers: top soil, presumably iron ore layer and weathered/fresh basement. The result of vertical electrical sounding curves showed a sudden drop in resistivity (42-241 $\Omega \mathrm{m}$ ) over high magnetic response. The geo-electric section revealed that the study area is generally characterized with thin overburden (0.5-1.7 m) and the thickness of the second layer (presumed to be the iron ore layer) ranged between 6.2-25.1 m. The study concluded that areas of high magnetic intensity showed a sudden drop in resistivity value for the VES points, which give an indication of the presence of an electrically conductive structure presumed to be iron ore deposits.
\end{abstract}

Key words: Iron ore, Tajimi village, ground magnetic, electrical resistivity, magnetic anomaly

\section{Izvleček}

Kombinirano površinsko magnetno in električno upornostno prospekcijo so izvedli z namenom, raziskati prisotnost in lego nahajališč železove rude pri vasi Tajimi v pokrajini Lokoja v severni centralni Nigeriji. Izdelana rezidualna karta površinskih magnetnih meritev, opravljenih na 250 merilnih postajah v 15 profilih, je razkrila številne izrazite anomalije pretežne N-S smeri. Radialni jakostni spekter nakazuje prisotnost magnetnih virov v globinah od $6 \mathrm{~m}$ do $20 \mathrm{~m}$. Interpretirani podatki vertikalnega električnega sondiranja (VES) omogočajo razdeliti območje na tri podpovršinske plasti: krovno plast, domnevno plast železove rude in preperelo in/ ali nepreperelo podlago. Krivulje VES nakazujejo nagel padec upornosti (42-241 $\Omega \mathrm{m}$ ) nad deli $\mathrm{z}$ visokim magnetnim signalom. Na geoelektričnih profilih je videti, da sta za preiskano območje v splošnem značilni tenka krovna plast $(0,5-1,7 \mathrm{~m})$ in debelina druge plasti (domnevno plasti železove rude) od 6,2 m do 25,1 m. Preiskavo so sklenili z ugotovitvijo, da nakazujejo območja visoke magnetne intenzitete, v katerih ugotavljajo na profilih VES nenaden padec upornosti, prisotnost električno dobro prevodne strukture, ki je domnevno nahajališče železove rude.

Ključne besede: železova ruda, vas Tajimi, površinska magnetna prospekcija, električna upornost, magnetna anomalija 


\section{Introduction}

Exploration for iron ore has been carried out using magnetic methods since the early 1900s. Both aerial and ground-based magnetic and radiometric techniques are commonly used for the detection of iron ore. Aerial techniques tend to be used at the reconnaissance stage, whereas ground-based techniques may be used for target appraisal. Aeromagnetic data cannot give details of magnetic structures of small dimension. Hence, the use of ground magnetic survey method to delineate the subsurface structure is important. An aeromagnetic survey for iron ore was carried out in some parts of Nigeria by the Geological survey of Nigeria in 1963. This led to delineation of notable occurrence of Banded Iron Formation (BIF) in some areas like Itakpe, Ajabanoko, Ochokochoko, and Tajimi among others. Ground magnetic survey has not been given much attention in the past; especially in a developing country like Nigeria. Magnetic survey sets out to investigate subsurface geology on the basis of anomalies causing magnetic field to result from magnetic properties of the underlying rocks [1]. It is also used in mapping geological boundaries between magnetically contrasting lithologies and structures like faults [2]. A magnetic anomaly originates as a result of the magnetization contrast between rocks with different magnetic properties. Most rocks contain some magnetite, hematite or other magnetic material, and will produce disturbances in the local magnetic field. Because of this, most soils and many man-made objects that contain nickel or iron have magnetic properties detectable by a sensitive magnetometer because they create local or regional anomalies in the Earth's main field. Anomalies are revealed by systematic measurement of the variation in magnetic field strength with position. This study presents results from integrated ground magnetic and electrical resistivity surveys around Tajimi village with a view to investigate the occurrence and subsurface geometry of iron ore deposits in the area.

\section{Location and Geological Setting}

Tajimi village is located in the north-central Nigeria. It lies between latitude $8^{0} 1^{1} \mathrm{~N}-8^{0} 3^{1}$ $\mathrm{N}$ and longitude $6^{0} 35^{1} \mathrm{E}-6^{0} 36^{1} \mathrm{E}$ (Figure 1). This area falls within the 1:100,000 published topographic map of Kabba sheet 246 of Federal survey of Nigeria. Tajimi is bounded to the east by Agbaja plateau and to the south by Obajana. The area is accessible by three minor roads from Obajana, Otokiti and Lokoja. Tajimi village is underlain by crystalline rocks of Precambrian Basement Complex of Nigeria [3]. It is specifically underlain by metasedimentary

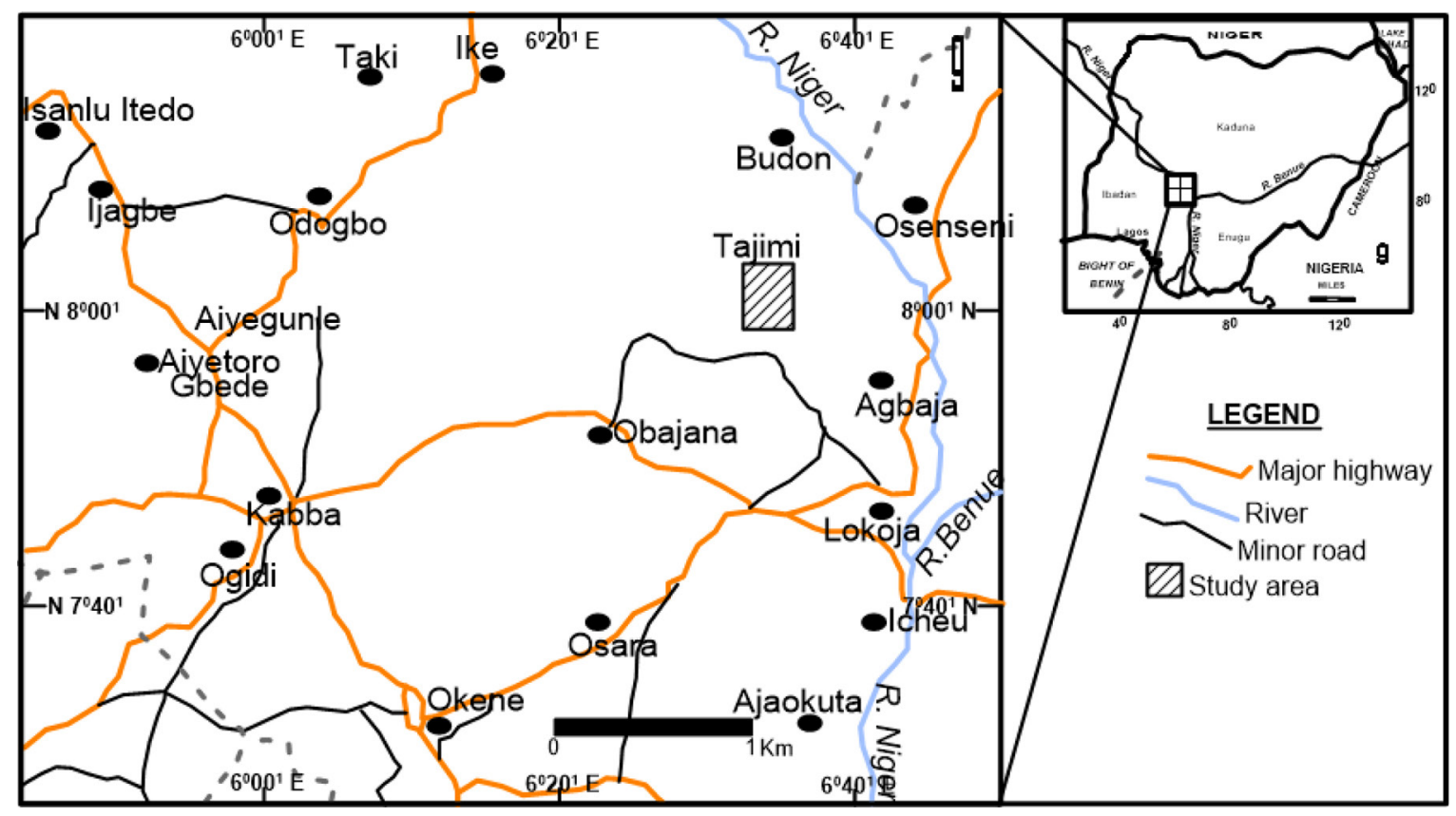

Figure 1: Location Map of Tajimi and adjoining areas (adapted from GSN map sheet 246, Okene SE) 


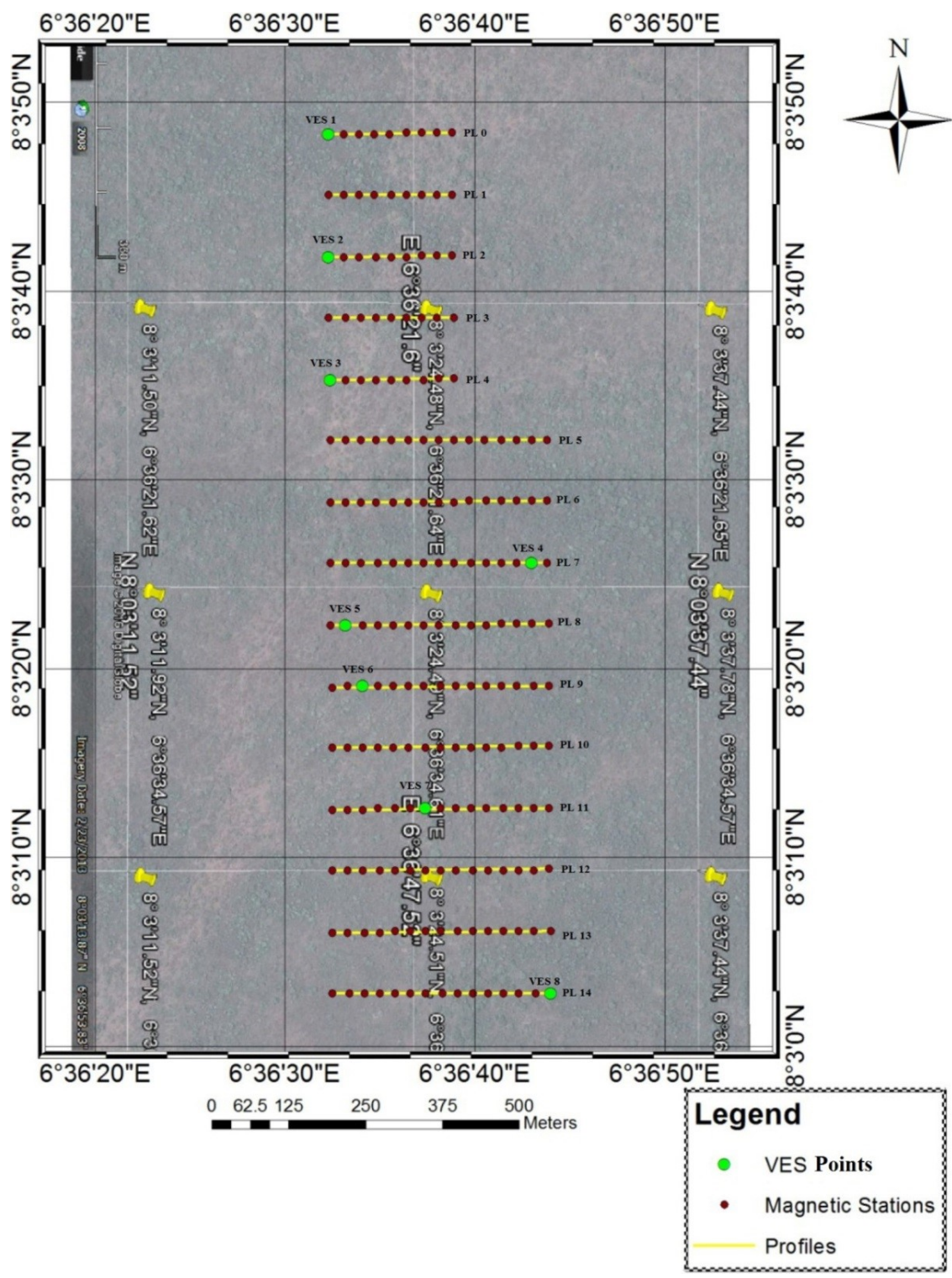

Figure 2: Base map of the study area showing traverses with magnetic stations and VES points

and metavolcanic rocks of Igarra, Kabba and Jakura regions. The dominant lithologic units are gneisses of migmatite, biotite and granite which are regionally emplaced, ferruginous quartzites, granites and pegmatite. Ferruginous quartzite is the source of iron ore mineralization in the area $[4,5]$.

\section{Methods}

In order to investigate the iron ore deposit around Tajimi village, a geophysical investigation involving Ground Magnetic Survey and Electrical Resistivity method was carried out.

\section{Ground Magnetic Survey}

Ground-based magnetic measurements were acquired with a G865 model of Proton Precession magnetometer along fifteen traverses with inter-traverse spacing of $500 \mathrm{~m}$ in the $\mathrm{W}$-E direction. Two hundred and one magnetic stations were occupied along the fifteen traverses with a nominal station of $25 \mathrm{~m}$ along the traverses (Figure 2). A base station established at the start of the magnetic survey was re-occupied every $2 \mathrm{~h}$ to correct for diurnal variation [6]. Figure 3 illustrates the record for magnetic field intensity variation during the survey. The geomagnetic gradient was removed from the diurnal corrected magnetic data using a math- 


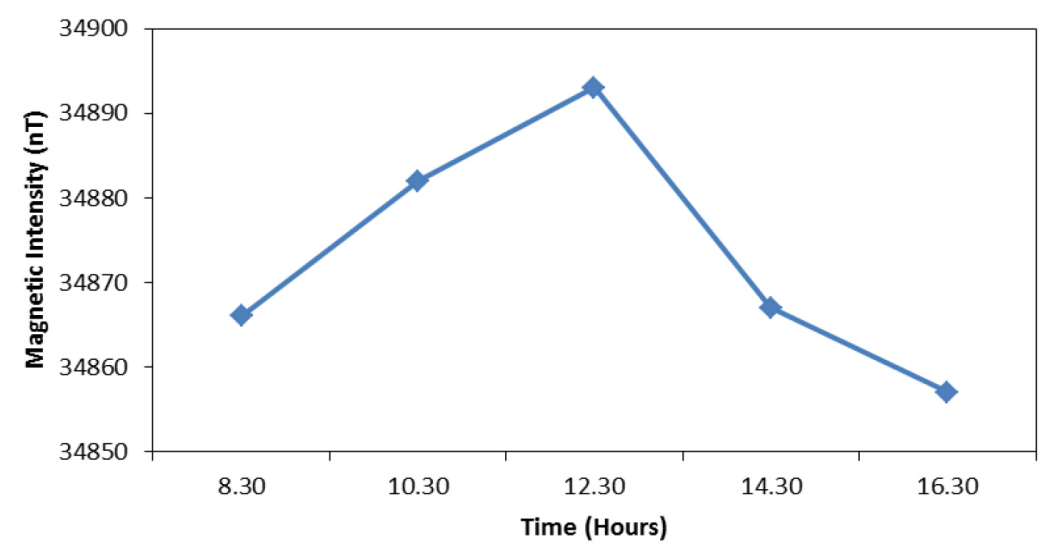

Figure 3: Diurnal variation in magnetic intensity with time during survey

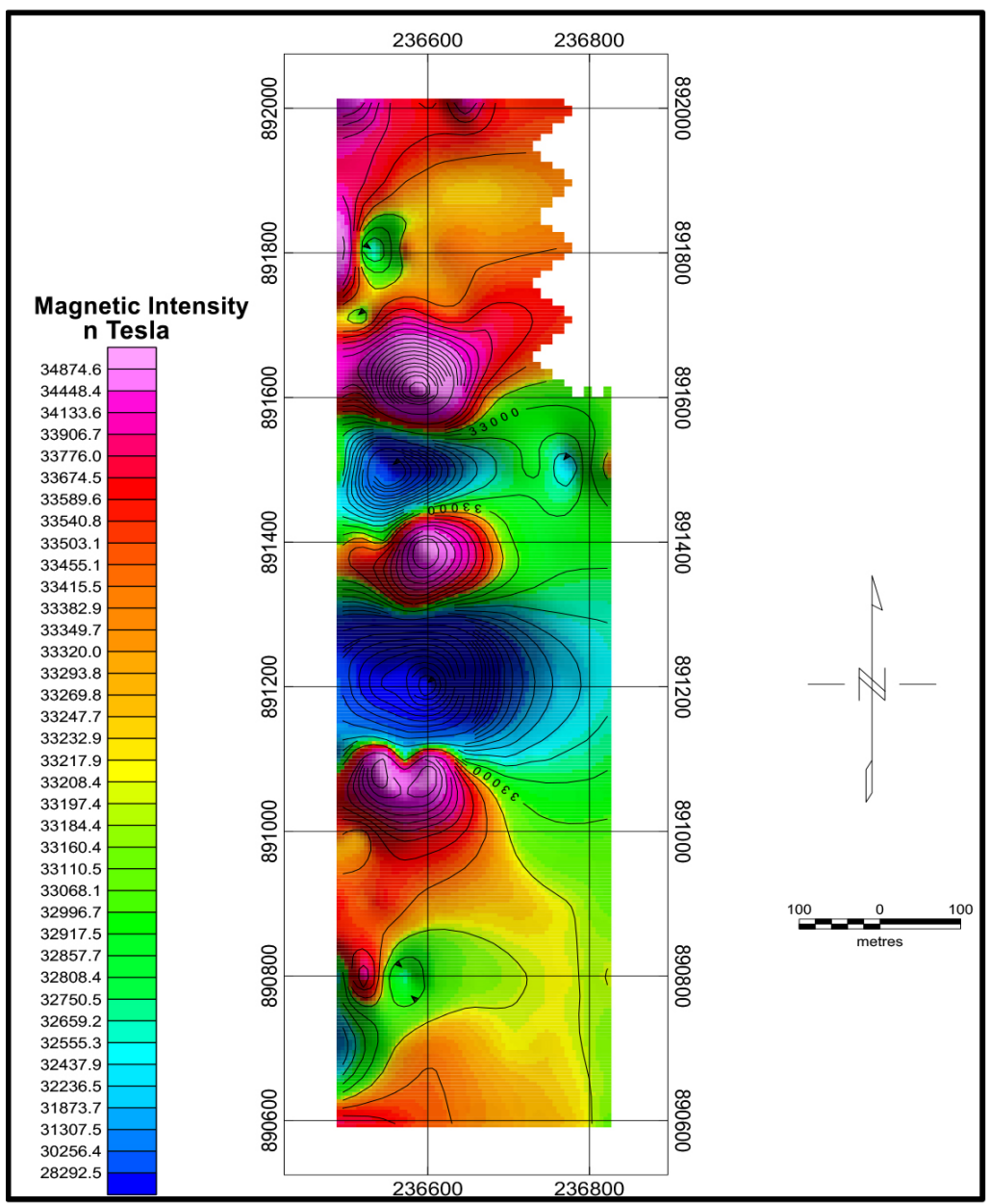

Figure 4: Total magnetic intensity map of the study area

ematical application based on the International Geomagnetic Reference Field (IGFR) model 2000-2015 obtained from http://www.ngdc. noaa.gov. Geomagnetic field parameters of the central location of the study area used for the gradient removal are: inclination $=-8.11^{\circ}$ and declination $=-6.32^{\circ}$. The resultant magnetic data was then used to generate a total magnetic intensity map of the study area, as shown in Figure 4. 


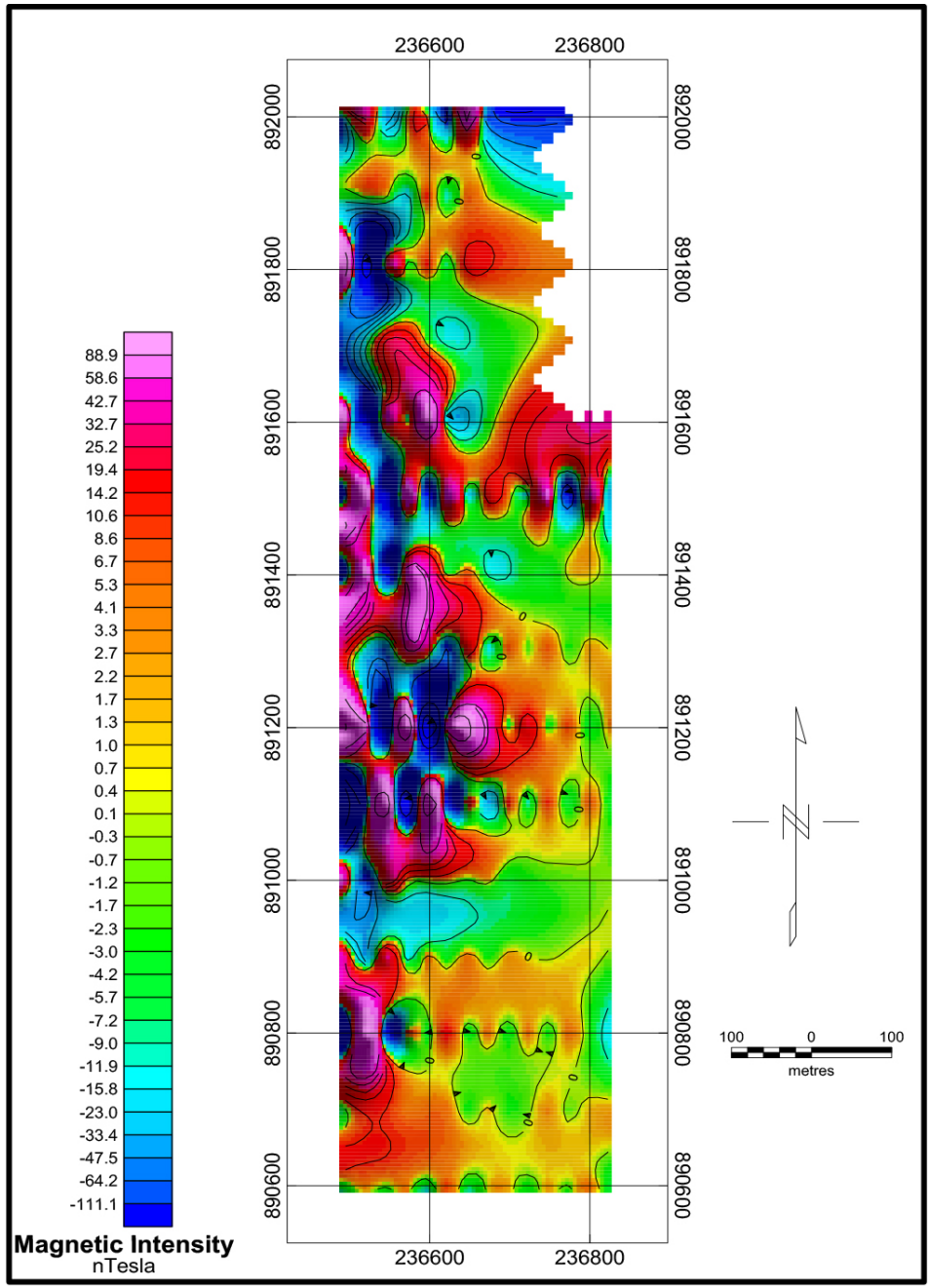

Figure 5: Residual magnetic intensity map of the study area

Analyses which included residualization and spectral analysis were carried out to improve the quality of the magnetic data for better understanding of the subsurface geology $[7,8]$. Residualization was done to remove the regional anomaly. This is achieved by application of the two-dimensional Fourier transform filter algorithm in the computer software Oasis Montaj ${ }^{\mathrm{TM}}$. The double Fourier transform of a space domain function of $\mathrm{x}$ - and $\mathrm{y}$ - coordinate is defined as:

$$
\begin{aligned}
F(\mu, v)= & \iint_{-\infty}^{\infty} f(x, y)\{\cos (\mu x+v y) \\
& -i \sin (\mu x+v y)\} d x d y
\end{aligned}
$$

where $\mu$ and $v$ are wave numbers defined by the wavelengths of magnetic intensity with respect to $\mathrm{x}$ - and $\mathrm{y}$ - coordinates. The two-dimensional
Fourier transform simplifies the operation of digitally filtering the magnetic anomalies. The resultant filtered magnetic data was then used to generate a residual magnetic intensity map of the study area (Figure 5). The application of spectral analysis to the interpretation of magnetic data allows the estimation of depth to the top of magnetic sources that produced the observed anomalies in magnetic maps $[9,10]$. The approach of plotting the computed radially average power spectrum of the Fourier transform magnetic data against the wave number [11] was employed in this study. The study area was divided into 7 blocks and average depth was computed for each block. Typical, the radially average power spectrum curve (Figure 6) of Tajimi magnetic data shows a nominal plot that has straight line segments, which decreases in slope with increasing frequency. 


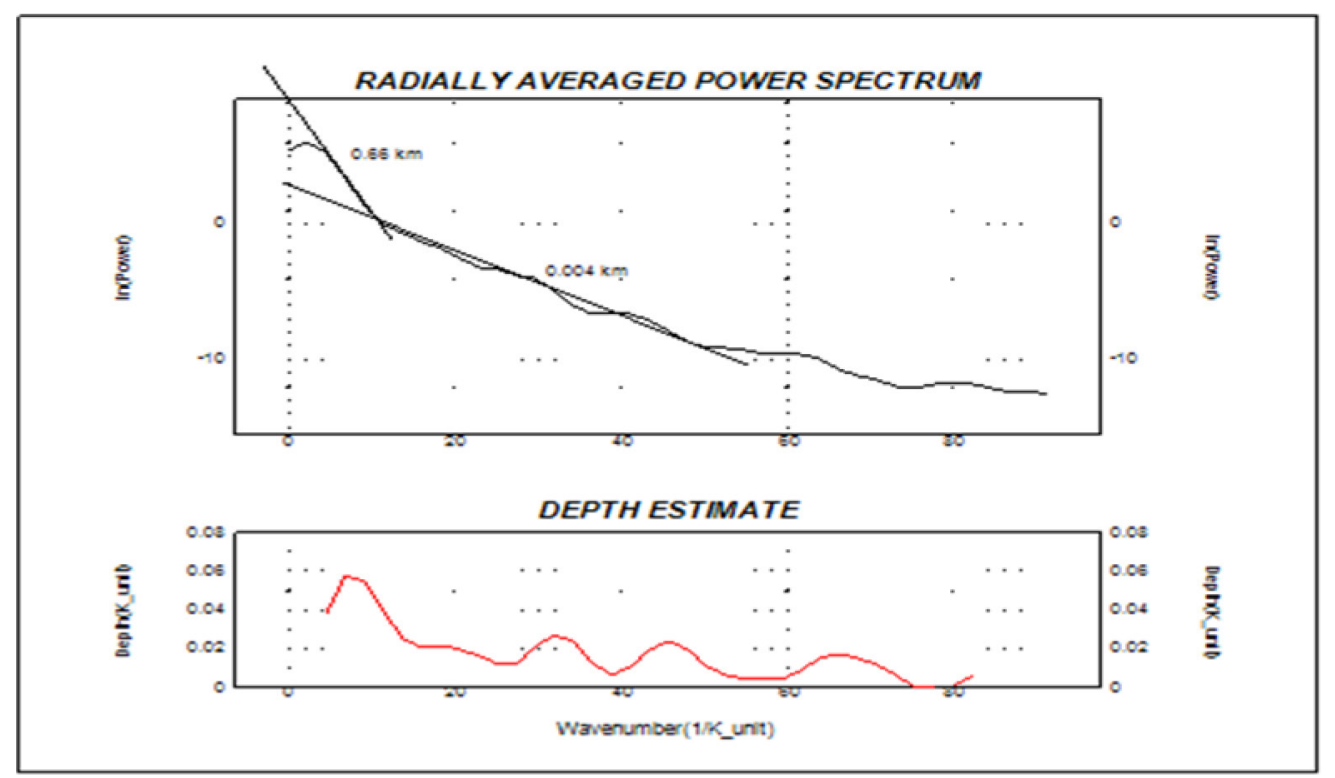

Figure 6: Typical radially average power spectrum plot

\section{Electrical Resistivity Survey}

Electrical resistivity survey was carried out using the campus omega terrameter at selected positions on the established traverses (Figure 2). Eight (8) vertical electrical soundings (VES) were carried out to determine the different elements of overburden, and also the depth to basement. The Schlumberger array was used. The VES data were presented as sounding curve plots of apparent resistivity against electrode spacing on a log-log graph sheet (Figure 7). Preliminary interpretation was carried out using partial curves matching, involving two-layer master curves and the appropriate auxiliary charts [12]. The layered Earth model thus obtained serves as input for 1-D computer assisted forward model using the WINRESIST computer software as a final stage in qualitative interpretation. The geo-electric sections were deduced from the interpreted parameters, and each geoelectric layer corresponded to a layer of uniform geological properties.

\section{Results and Discussion}

\section{Ground Magnetic Data Interpretation}

The total magnetic intensity map (TMI) of Tajimi village is presented in Figure 4. The TMI map shows the magnetic intensity distribution over the study area typified by low and high magnetic anomaly values ranging from 28292.5 nT to 34874.6 nT. Three areas - southern, central and northern part of the study area - are characterized by high magnetic signature ranging between $33906 \mathrm{nT}$ to $34874 \mathrm{nT}$. The residual magnetic intensity map (Figure 5) shows magnetic intensity amplitude ranging from $-111.1 \mathrm{nT}$ to $88.9 \mathrm{nT}$, suggesting contrasting rock types in the basement of the study area. The residual map shows numerous prominent positive anomalies, mostly trending $\mathrm{N}-\mathrm{S}$, characterizing the western part of the study area. These anomalies are characterized by relative higher magnetic intensity values ranging from $32.7 \mathrm{nT}$ to $88.9 \mathrm{nT}$, which are related to the occurrence of iron ore in the area. In between the positive anomalies, there are areas of relatively low magnetic intensity values $(-689$ to -3584$)$. The negative anomalies are probably associated with granitic intrusions $[13,14]$ or concealed structures like fractures and/or faults $[15,16]$. The spectra plots for Tajimi magnetic anomalies show two tangential straight line segments suggesting two main source-depths for the positive anomalies in the area (Figure 6). The peaks within the first line with the greatest slope give the depth estimate of the deepest source, while the peaks within the second line with the least gradient give the shallowest source. These estimate the depth to magnetic sources in the area ranging from $6 \mathrm{~m}$ to $20 \mathrm{~m}$. 


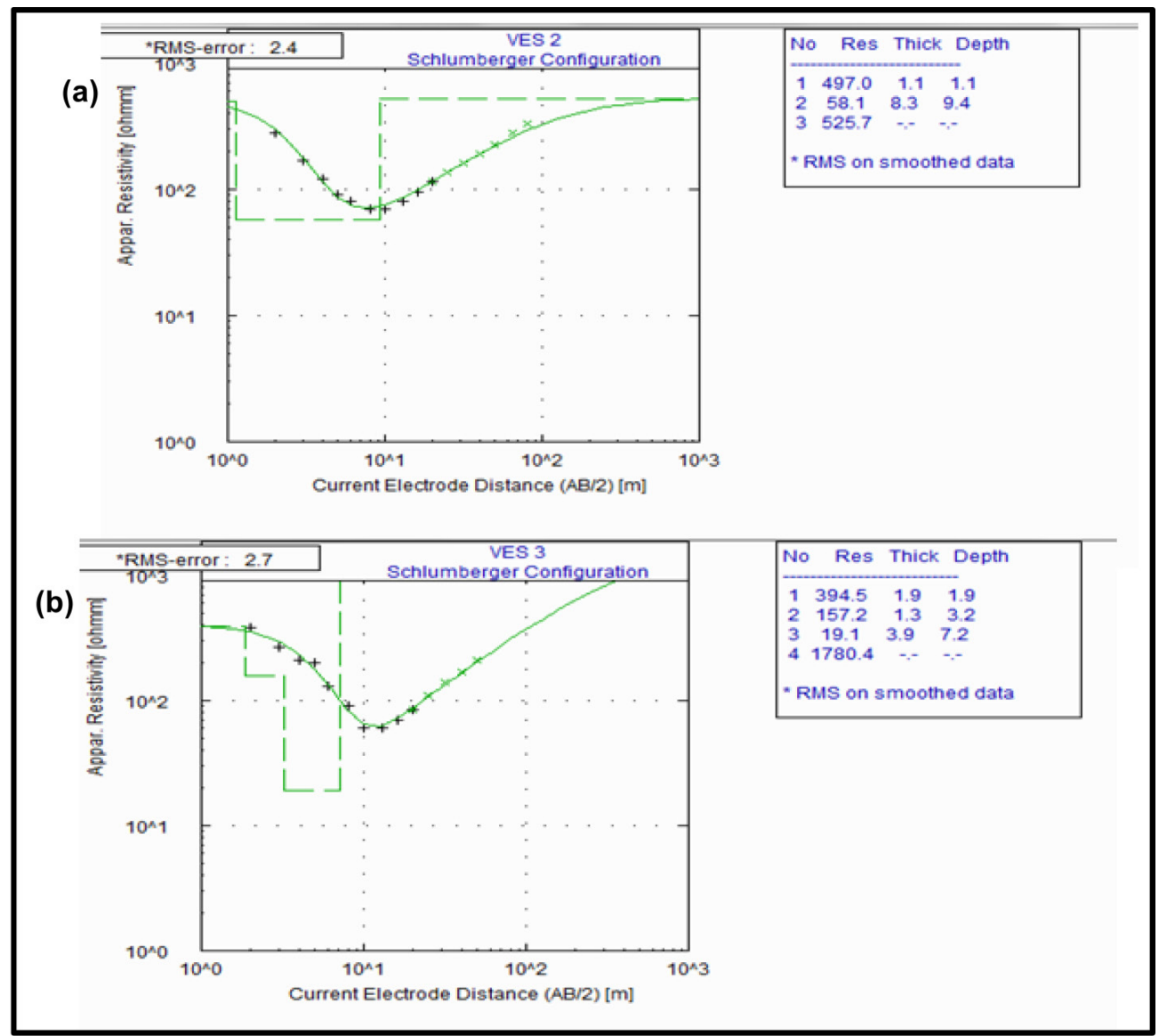

Figure 7: Typical VES curves of resistivity against depth. (a) H-type curve (b) QH-type curve

\section{Electrical Resistivity Data Interpretation}

Typical VES curve of resistivity $(\Omega \mathrm{m})$ against electrode separation $(\mathrm{m})$ is shown in Figure 7. $\mathrm{H}$ and $\mathrm{QH}$ type curves are the dominant VES curves obtained for the sounding points. Qualitative and quantitative interpretation of the resistivity data revealed a range of three to four layer Earth models (Figure 8). The three layer models are characterized by $\mathrm{H}$ curve type, while the four layers exhibit QH curve type. The interpreted subsurface layers include top soil (lateritic), anomalous low resistivity layer (iron ore zone), weathered/fractured basement and fresh basement. The topsoil is thin (approximately 0.5-1.7 m thick) composed of lateritic sand overlying a moderately thick and low resistive layer. This second layer appears to be the iron ore zone of about $6.2 \mathrm{~m}$ to $25.1 \mathrm{~m}$ thick and resistivity value of $42-241 \Omega \mathrm{m}$. The third layer represents the weathered/partly weathered fresh basement.

\section{Conclusions}

Integrated ground-based magnetic and electrical resistivity methods were used to investigate the occurrence and geometry of iron ore in Tajimi village, Lokoja, north-central Nigeria. The ground-magnetic data were acquired at 250 stations along 15 traverses trending W-E direction. The interpreted residual magnetic map revealed numerous prominent positive anomalies mostly trending N-S, characterized by relative higher magnetic intensity values ranging from 32.7 nT-88.9 nT. These anomalies are related to the occurrence of iron ore in the area. Spectral analysis of the magnetic data suggests the existence of two main source depths which range from $6 \mathrm{~m}$ to $20 \mathrm{~m}$. The interpreted VES data characterized the area into three subsurface layers: top soil, anomalous low resistivity layer (iron ore zone) and weathered/fractured bedrock. The topsoil is thin (approximately 


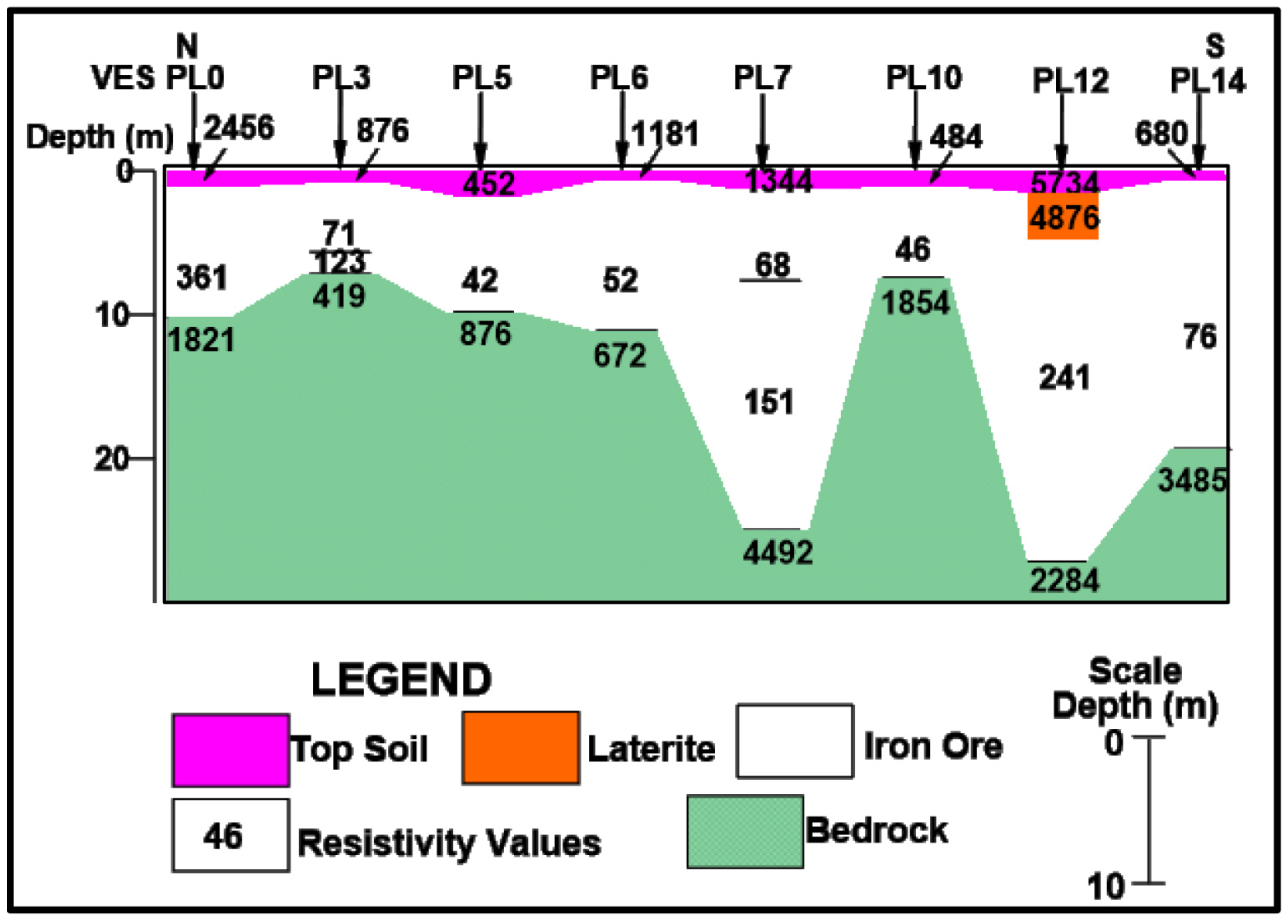

Figure 8: Generated geo-electric section from the VES surveys across the traverses

0.5-1.7 m thick) composed of lateritic sand overlying a moderately thick and low resistive layer, which appears to be the iron ore zone of about $6.2 \mathrm{~m}$ to $25.1 \mathrm{~m}$ thick with resistivity value range of between $42-241 \Omega \mathrm{m}$. The third layer represents the weathered/partly weathered fresh basement with resistivity range of between $419 \Omega \mathrm{m}$ to $4492 \Omega \mathrm{m}$.

The estimation of thickness of the iron ore deposit by ground magnetic survey ( $6 \mathrm{~m}$ to $20 \mathrm{~m}$ ) and VES (6.2 $\mathrm{m}$ to $25.1 \mathrm{~m}$ ) are in accordance. The area with high magnetic intensity in the residual magnetic intensity map corresponds with the area indicated with low resistivity values in the 2D geoelectric section obtained from the VES data interpretation.

The occurrence of iron ore deposit has been established using the integration of ground magnetic and electrical resistivity survey conducted within Tajimi village. The depth estimate of the deposit from the two geophysical methods is in good accordance. However, coring, chemical analysis and complimentary geophysical prospecting are recommended to deduce the iron ore type and estimate the proven tonnage of the iron ore formation in Tajimi village.

\section{References}

[1] Philip K., Micheal, B. and Ian, H. (2002): An introduction to Geophysical exploration (3rd edition), Blackwell Science Ltd, $168 \mathrm{p}$.

[2] Telford, W.M., Geldart, L.P., Sheriff, R.E. (1991): Applied Geophysics (2nd edition), Cambridge University Press, $792 \mathrm{p}$.

[3] Rahaman, M.A. (1988): Recent Advances in the study of the Basement Complex of Nigeria. In: Precambrian Geology of Nigeria, Geological Survey of Nigeria Publication, pp. 11-43.

[4] Olade, M.A. (1978): General Features of a Precambrian Iron Deposit and its Environment at Itakpe Ridge Okene, Nigeria. Transactions of Institution of Mining and Metallurgy, Section B, 87, pp. 81-89.

[5] Fadare, V.O. (1983): Iron Ore Formation-The OkeneAjaokuta-Lokoja areas of Kogi State. A potential supply base for steel plant at Ajaokuta, Journal of Mining and Geology, 20, pp. 209-214.

[6] Riddibough, R.P. (1971): 'Diurnal corrections to magnetic surveys', An assessment of errors. Geophysical prospecting, 19(4), pp. 551-567.

[7] Blakely, R.J. (1996): Potential Theory in Gravity and Magnetic Applications (2nd edition). Cambridge University Press, $464 \mathrm{p}$. 
[8] Hildenbrand, R., Hinze, W. Keller, G.R., Labson, L. and Roest, W. (2003): New and unique U.S. magnetic database is forthcoming. The Leading Edge, 22, pp. 234 244.

[9] Hahn, A., Kind, E.G. and Mishra, D.C. (1976): Depth estimation of magnetic sources by means of Fourier amplitude spectra. Geophysical Prospect, 24, pp. 287308.

[10] Nur, M.A, Onuoha, K.M. and Ofoegbu, C.O. (1994): Spectral Analysis of Aeromagnetic data over the Middle Benue Trough, Nigeria. Journal of Mining and Geology, 30, pp. 211-217.

[11] Ofoegbu, C.O. and Onuoha, K.M. (1991): Analysis of magnetic data over the Abakaliki Anticlinorium of Lower Benue Trough, Nigeria. Marine and Petroleum Geology, 8, pp. 174-183.
[12] Rijkswaterstaat, (1978): Standard graphs for resistivity prospecting. European Association of Exploration Geophysicists, 167 p.

[13] Mume, W.G. (1964): Negative total-intensity magnetic anomalies in the southeast of south Australia. Journal of Applied Geophysics, 32, pp. 213-217.

[14] McEnroe, S.A., Skilbrei, J.R., Robinson, P., Heidelbach, F., Langenhorst, F., Brown, L.L. (2004): Magnetic anomalies, layered intrusions and Mars. Geophysical Research Letters, 31, L19601.

[15] Parasnis, D.S. (1986): Principles of Applied Geophysics. Chapman Hall, London, 260 p.

[16] Fieberg, F.C. (2002): Ground magnetic investigations for gold prospecting in south-western Nigeria. Abstract, presentation at $62^{\text {nd }}$ meeting of German Geophysical Society, Hannover, 20 p. 
